\title{
Design and Co-Design of Project-Organized Studies
}

Nielsen, Jørgen Lerche; Birch Andreasen, Lars

Published in:

Situated Design Methods

\section{Publication date:}

2014

\section{Document Version}

Early version, also known as pre-print

\section{Citation for published version (APA):}

Nielsen, J. L., \& Birch Andreasen, L. (2014). Design and Co-Design of Project-Organized Studies. In J. Simonsen, C. Svabo, S. M. Strandvad, K. Samson, M. Hertzum, \& O. E. Hansen (Eds.), Situated Design Methods (pp. 43-58). MIT Press. Design thinking, design theory No. [6]

\section{General rights}

Copyright and moral rights for the publications made accessible in the public portal are retained by the authors and/or other copyright owners and it is a condition of accessing publications that users recognise and abide by the legal requirements associated with these rights.

- Users may download and print one copy of any publication from the public portal for the purpose of private study or research.

- You may not further distribute the material or use it for any profit-making activity or commercial gain.

- You may freely distribute the URL identifying the publication in the public portal.

Take down policy

If you believe that this document breaches copyright please contact rucforsk@kb.dk providing details, and we will remove access to the work immediately and investigate your claim. 


\title{
Design and Co-design of Project- organized Studies
}

\author{
Jørgen Lerche Nielsen, and Lars Birch Andreasen
}

\begin{abstract}
What. The chapter contributes to discussions on design processes in relation to education. Different notions of design research are presented. It is demonstrated how professors and students are involved together in designing innovative and constructive study processes that can help fostering students' engagement, self-awareness, mutual evaluation, reflection, and critical and creative thinking. The case to be presented and analyzed is the Master program ICT and Learning (MIL), where Roskilde University is partner in the crossinstitutional collaboration behind the program.

Why. It is a challenge for the educational system to meet the new needs for competencies, due to the change from an industrial society to a knowledgebased society. The problem-based approach can be seen as attempts to meet these challenges. Unlike a classic curriculum-oriented and teacher-steered model, project work is open ended and directed at handling unknown and dynamic processes.

Where. Problem-based approaches are relevant for master programs with a need for collaboration, flexibility and implementation of technologies to overcome time, space and geographical limitations, and for study programs, where students are involved in self-directed study practices, and where there is a need for continuing reflective processes of how to learn. In relation to the Humanistic Technological Bachelor program at Roskilde University (Hum Tech), it is relevant to reflect on designs for learning in relation to both experimental use of and analytical dimensions of new technologies.

How. The methodological approach deals with developing designs for learning that involves students as co-designers through problem- and project-based learning. The approach can be applied by professors and students who collaboratively wish to develop their study programs. In the situated context of problem-based learning, we discuss how students can plan and continually redesign their project work, how a balance of verbal and written activity can be maintained, and how social media can support group processes.
\end{abstract}




\section{Introduction}

In this chapter we will show how design research can be related to the field of learning and how professors and students can design innovative and constructive study processes that can help meet competencies needed in a knowledge-based society. We will discuss the tradition of designs for learning (Selander, 2008) and its contrast instructional design. Furthermore, we will try to show how the introduction and spreading of information and communication technologies (ICT) within the last decade has set a new agenda for learning designs in schools and universities. We will have a special focus on problem- and project-based studies, as they have developed in Denmark since the beginning of the 70s. Our case will be the Master program in ICT and Learning (MIL), where Roskilde and Aalborg Universities are partners in the cross-institutional collaboration behind the program.

As an alternative to more curriculum-oriented teaching approaches, problemand project-based learning have developed over the last decades into an institutionalized approach (Barron et al., 1998; Olesen \& Jensen, 1999; Kolmos et al., 2004; Andreasen \& Nielsen, 2013). In this approach focus is on exploring and working with problems as a didactic method. PBL offered a new perspective to the existing teaching practice, a perspective where students, instead of only listening to professors lecturing, gained their own experiences through working with practical cases - scenarios, visual prompts, design briefs, puzzling phenomena or some other triggers, often based in real-life that may mobilize students to learn (Barrett \& Moore, 2011, p. 4). Frank and Barzilai state that students who worked in a problem-based learning environment were likely to engage themselves in processes of active learning and gain multidisciplinary knowledge, and note that "the PBL environment [...] increased students' self-confidence, motivation to learn, creative abilities, and self-esteem" (Frank \& Barzilai, 2006, p. 40).

In a Danish context the approaches of problem- and project-based learning were developed at the universities of Roskilde and Aalborg, with an emphasis on collaboration and student-directed project work (Dirckinck-Holmfeld, 2002; Kolmos et al., 2004; Olesen \& Jensen, 1999). In relation to this approach a central task, which will be explored in this chapter, is how to develop designs for learning that may engage students in taking responsibility for their learning process. A challenge in this process is how teachers can help students to relate curriculum and theories to praxis. Thus, the methodological approach to be introduced and discussed in this chapter is developing designs for learning that involves students as co-designers through problem- and project-based learning.

In relation to the MIL case we have been involved as practitioners designing curricula, study sequences and together with our students designing frames for problem-based learning processes. This explorative endeavor covers both faceto-face learning environments (on-site) and networked learning environments 
(online). We will be examining how professors and students together are trying to create productive learning environments, and the implications of this for the professor-student-relationship. It should be noted that we in this chapter generally use the term "professor" to cover as well professor, associate professor, teacher, lecturer, assistant professor, etc.

In relation to the Humanistic Technological Bachelor program at Roskilde University (Hum Tech), it is relevant to reflect on how study processes - in relation to both experimental use of and analytical dimensions of new technologies - can be designed and draw inspiration from the examples mentioned above.

\section{Design-based research and education}

The term 'design experiments' was first introduced in relation to education in articles by Ann Brown (1992) and Allan Collins (1992). Previously educational research in the USA to a high degree took place in controlled and fairly isolated environments, typically within laboratories, but since the beginning of the 90s there has been a lively debate on how 'design-based research' or just 'design research' may have relevance for education and the understanding of learning processes. Using a design-based research approach in education central characteristics will be (Collins et al., 2004, p. 16; Barab \& Squire, 2004):

- Approaching the study of learning phenomena situated in real world settings through ethnographic methods rather than isolated laboratory studies

- Producing new insights and theory through interventions in praxis

- Conducting iterative processes, cycles of designing, implementing, analyzing, evaluating and redesigning

- Involving researchers as well as practitioners

- Applying a pragmatic approach oriented towards improving the setting of the intervention

New paradigms emerged with a greater focus on how learning and knowledge are created through the interaction and active participation of students in the learning processes. "[L]earning, cognition, knowing, and context are irreducibly co-constituted and cannot be treated as isolated entities or processes", as underlined by Barab and Squire (2004, p. 1). Their argument is that a fuller understanding of how learning occurs should be reached in 'messy' real life circumstances, where the study processes are explored situated in their social context. Within the last decade special issues of educational journals have been published to examine this field, for example Educational Researcher (vol. 32, no. 1 (2003), edited by Kelly \& Bell), Journal of The Learning Sciences (vol. 13, no. 1 (2004), edited by Barab \& Squire), Educational Psychologist (vol. 39, no. 4 (2004), edited by Sandoval 
\& Bell) and Journal of Computing in Higher Education (vol. 16, no. 2 (2005), edited by MacKnight).

In Denmark the debate has taken quite another direction. Lab research within isolated controlled environments has been rare. Instead practice-oriented research focused on the specific situatedness has been conducted within schools and educational institutions and often in connection to efforts directed at reforming schools through practical experiments and developmental projects. More recently the term design-based research has been discussed in relation to education (Ejersbo et al., 2008; Christensen et al., 2012). In 2012 a special issue of the Danish online journal "Læring og Medier" (Learning and Media) (vol. 5, no. 9 (2012), edited by Pedersen, Löfvall, Dalsgaard \& Bang) was dedicated to design-based research. The effort is to create a better understanding of the different processes connected to research and intervention in learning situations. By following the iterative processes of design-based research thorough investigations can be carried through. Various kinds of data - ethnographic observations, recordings of logs, diary notes, online contributions, audio or video recordings, interviews, and quantitative data from surveys - may contribute in order to re-define the problems, propose possible solutions and principles that might address them. As data are reexamined and reflected upon, new designs are created and implemented, producing a continuous cycle of design-reflection-design.

This iterative design method has similarities with the action research and the participatory design research traditions. Here also the common goal for practitioners and researchers is to achieve more satisfying and democratic practices. For the researcher or designer the practitioners are seen as valuable partners in identifying problems, developing solutions, help establishing research questions, and supporting mutual learning (Simonsen \& Robertson, 2013), and there is a widespread tradition in the US, Australia, UK, and the Scandinavian countries for transforming the action research approach to action learning for the involved participants (Revans, 1982; Kemmis \& Wilkinson, 1998).

\section{Case analysis: Design of project work}

We will now turn to the case of the MIL program and discuss how we as a team of professors continually have been working on designing and redesigning the educational program in interaction with the students.

\subsection{The Master program in ICT and Learning (MIL)}

The case to be discussed in the following comes from the Danish postgraduate Master program MIL, which is a part-time program. Most of the students are employed full-time or part-time while studying, and the students come from 
all parts of the country. The MIL program was established in 2000 and is being offered as a joint program between four Danish universities.

The program builds on a networked learning structure and combines on-site seminars with online periods of course activities and project work. Pedagogically, the program builds on principles of student engagement in formulating research questions, investigating exemplary problems, and using interdisciplinary approaches. In their projects, the students study research problems from their own work practice, applying theories, concepts and methods from the academic practice. Thus, the Master program is a development of problem and project-based learning, adapted to the virtual study environment.

The virtual learning environment used at MIL combines an e-learning platform with various open online facilities. The e-learning platform FirstClass contains asynchronous and synchronous communication and collaboration facilities, file sharing, individual mailboxes and profiles, a who-is-online facility, and student groups have their own virtual folders to save, share, and organize their contributions. In addition to this, the students also use synchronous video meeting facilities (Adobe Connect, Google Hangout), peerto-peer tools and web 2.0 facilities (Skype, Messenger, Google Docs, Facebook, blogs), and tools to support project and course work (e.g. Camtasia for screen recording, Zotero for reference handling).

In the following we will present how MIL students in problem-based and project-organized studies work with their master projects and act as codesigners of learning activities.

\subsection{Developing 'master projects'}

For MIL students working with projects provide a possibility for them to dive deeper into a problem they have a wish to clarify, thus supplementing their previous course activities.

At MIL the main part of the spring semester is dedicated to working with student-directed projects. At one of the preceding face-to-face seminars the students have started a process of developing and negotiating which problems and research questions to focus on. A brainstorming event is organized, where proposals are lined up and students get a first idea of which themes could be relevant or possible and which groups could be formed. These initial discussions are followed by online dialogues during the following months, where students are continually presenting potential topics for projects, and negotiating among them. Some students develop further on themes derived from courses and seminars in the previous semesters; others move into new areas. Taking part in a group is encouraged, but it is also possible for students if they wish so to work individually on a project. Professors at the program are allocated as supervisors/facilitators for the projects. 
Master projects are often written by groups, where one of the members are "insider" in relation to the case or organization being studied, while the other(s) are "outsiders" (Dirckinck-Holmfeld et al., 2008, p. 178). The insider will often have a deeper knowledge of the case and will be able to facilitate access to contacts, places, etc. It may however be difficult to study practices you are involved in and to establish the view from a distance that is also necessary to study a case. As Alvesson states, "[t]he challenge of ethnography, and of most qualitative work, is to be close and avoid closure" (Alvesson, 2003 , p. 190). For a group in this situation the group members that are outsiders will be able to challenge understandings and pose critical questions. The possibilities of such collaboration in a master project lie in the meeting of different perspectives, not by uncritically combining both, but through constantly being challenged in the students' assumptions and interpretations of their material.

While creating papers for their project, the students are constantly reflecting on the processes they are engaged in. What insights do they achieve? What do they learn during the process? What can they eventually do otherwise next time in a similar situation? In relation to gain benefit of group collaboration processes, a student explains that "we were not good in putting things down in writing, but on the other hand we were really good at talking and talking at our Skype meetings." (Male student at MIL, our translation). It is a well-known dilemma to establish a practice where groups not only talk and unfold ideas, but also capture these ideas in writing. The process of writing may be hard work, but it often contributes to clarifying the students' ideas. This dilemma can be seen as a parallel to Wenger's discussion of the importance of the interplay between participation and reification, between the momentary process of generating ideas and the long stretch of forming products and results (Wenger, 1998). Both processes are necessary parts of productive group collaboration.

Another challenge for groups is to establish and maintain an overview of decisions, materials, and texts produced during the process: "Like all other project groups who work $99 \%$ through mail or conferences in e.g. FirstClass, we have in our group had difficulties in maintaining overview of our work. I think we have been constrained by not having met face-to-face to clarify deadlines and other questions that needed to be decided." (Student at MIL, our translation). This student points at some of the difficulties that may arise when working only asynchronously, in this case through e-mail and in web conferences. A face-to-face meeting as suggested by the student might have eased the process, but there are also a number of online web 2.0 facilities available to make it easier for groups to create and share resources, connect to others, interact and work collaboratively across time and space. The group of students might for example have gained a better overview by expanding the traditional asynchronous tools with storage facilities that allow revision control ("Where is the newest version of this chapter?"), or easy manageable 
online spaces to share various kinds of materials of a group, e.g. Dropbox or Google Drive. Moreover, the problem of decision-making could be helped either through a Doodle (e.g. for small polls or decisions on dates) or through synchronous tools like Skype, Google Hangout or Adobe Connect that might facilitate their decision-making processes better than asynchronous tools.

As pointed out by O'Reilly, web 2.0 has made it possible for users of the Internet to engage in processes of 'harnessing collective intelligence' through easing the conditions for collaboration, sharing, and active learning (O'Reilly, 2007, p. 22). It is noteworthy how the relatively big changes of users' work practice that follow from working with web 2.0 tools, often seamlessly become an integrated part of the way of working.

When dealing with online project-organized learning activities, as in the MIL program and Hum Tech at Roskilde University, where students are engaged in making analysis of complex matters and doing experimental and construction based projects, the professor's main role is not solely as a lecturer or instructor, but as a supervisor. As Kahiigi et al. suggests: "The teacher takes on a facilitator role while the students take ownership of their learning and personal development" (Kahiigi et al., 2008, p. 82). Some of the MIL students reflected on the relation between supervisor and students and the role of a teacher as a supervisor. One student indicated in retrospect that their group had made too little use of supervision. Another student pointed out the pitfalls of relying too much on supervision and advised not to turn on the 'automatic pilot' when being supervised: "A supervisor meeting may cause a kind of tunnel vision, because you have a tendency to follow the guidelines from the supervision very strictly." (Student at MIL, our translation). This highlights the reciprocity of the relationship between students and supervisor. As a supervisor the professor may act as a coach, a mentor, a discussion partner; as one who supports as well as challenges the students in their project work.

A supervisor should not just give the students what they want, but should instead stimulate the students to transgress their familiar abilities and to enter new areas of activity. A supervisor can do this proactively in relation to the students' projects showing possible ways to go for the students, but at the same time without taking too much responsibility. There is thus a delicate balance for a supervisor between being outwardly pushing or patiently waiting, as a student writes: "The ideal supervisor is a person that understands how 'to feed', but also to hold back, in order for the expertise of the group to unfold." (Student at MIL, our translation).

Based on our experiences from teaching at the MIL program, we will point out that teaching online creates a need for technological as well as social awareness, where professors should be visible and accessible, in other words mobilize tele-presence. The challenge for the professor is to allow adequate space for students to operate and navigate, but at the same time provide clear criteria and standards to make sure students understand the tasks and activities. 
Especially in online activities it is important to assist the students to stick to their work and hold on to their plans.

Through the problem- and project-based method of studying, students can thus actively engage themselves by participating in and designing their own collaborative work processes. We will in the following point out some crucial aspects students have to deal with in this process.

\section{Students designing and having ownership of their project}

In a problem- and project-based learning environment it is important for participants to support one another in finding new ideas for relevant, challenging, and multi-faceted problems to work with. The starting point of a student group's independent work on a project is to choose a topic or a problem to develop that represents a challenge to them. This is similar to what the cultural anthropologist Michael Wesch underlines as the importance of supporting students' ability to wonder. The process of defining a problem involves questions such as: What are the meanings of this problem? Why should we try to solve it? How did it emerge? What could we aim to design, for what purpose and for whose benefit? Working with questions like these can be a challenging, but productive process. Furthermore, it is interdisciplinary in that it may combine knowledge and ideas from different kinds of academic fields as underlined by Olsen \& Pedersen (2005).

Students participating in project groups should learn to combine the ability to plan ahead with the ability to act ad hoc. In this combination of planning and acting, group decisions may deal with questions like what to do next, who should do what, and when in the process particular tasks should be undertaken? In this process continuous redesign of the plans is a necessity. This is framed by Karl Weick's concept of 'improvisational design', according to which tasks and surroundings are viewed as dynamic, complex processes, where activities only tentatively and through continuing iterations can be planned. It is therefore necessary for the participants - be it students, professors or designers - to engage in dialogues and negotiations in order to reach strategies for action (Weick, 2001, p. 57ff). This can be related to coping with the unknown and unexpected challenges confronting a student group. The collaborative processes of project work can be frustrating, but by not being overwhelmed they can also hold possibilities of new understandings, and thus a certain amount of frustrations can be used as potentials for learning.

In the process of reflecting on and clarifying their research question, students learn how to plan, manage, and evaluate projects. In this process Schön's $(1983,1987)$ concept of 'reflection-in-action' as well as 'reflection-on-action' could be applied. Schön points to the ability of professionals to "think about what they are doing while doing it" (Schön, 1983, p. 275). For students collaborating, it is crucial to be aware of what they are doing, and how they 
are interacting while they are doing it. Also after meetings and preparing for new meetings it is important to reflect on what was going on last time, how can we if necessary do things in other ways and what initiatives should in the future be taken? Students' ways of dealing with the continuous evaluation of their situation and eventually re-design of their plans are central to their process. Do they stick firmly to agreements made earlier, or do they revise according to new needs?

The situation, where students as demonstrated above are designing and having ownership of their own learning process, has not always been the case within the field of education. To further elaborate the competing notions of education in play, we will below discuss the development in educational paradigms, from the curriculum-oriented instructional design approach to a more learnercentered and dynamic approach.

\section{From instructional design to designs for learning}

A school of thought in the field of technology and education, which have influenced many educational approaches, is the paradigm of instructional design. Developing since the 1940s, focus of the instructional design approach has been to develop effective designs for instruction and teaching that are generally applicable for the teacher. Instructional design refers to development and construction of educational systems of fixed nature, which can be easily used by the instructor in any learning process. The course, its content and materials are standardized in the same way as the methodological conception of the course. We discuss in this chapter the approach of instructional design in contrast to the concept of designs for learning, where focus is on how to design for learning processes to happen in situated contexts.

The concept of instructional design has its roots in behaviorism - focusing on external stimuli, observation of actions, and the ability to measure learning outcome - and in cognitivism - focusing on information processing and on instruction as transmission of information - in its view of learning activities (Harasim, 2011, p. 41 \& 52). The original idea of instructional design can be said to reflect the surrounding environment of the industrial age with its standardization and assembly lines. In relation to education Staffan Selander describes this situation as a: "world of prefabricated learning resources, formalized work and strict time-tables (lessons). The role of the teacher is to 'bring' knowledge to the student, and the student's role is to remember by heart and to learn specific skills" (Selander, 2008, p. 14). The instructional design approach aims to transmit knowledge to the students as efficient as possible. Karl Weick captures this situation by his 'architectural' metaphor: "Organizational design modelled along the lines of architectural design is viewed as a bounded activity that occurs at a fixed point in time" (Weick, 2001, p. 57). Plans that are made through this approach envision structures rather than processes. In a text directly related to education Weick states that 
"preoccupation with rationalized, tidy, efficient, coordinated structures has blinded many practitioners as well as researchers to some of the attractive and unexpected properties of less rationalized and less tightly related clusters of events" (Weick, 1976, p. 3), thereby pointing out the affordances of a more fluid approach, not bound by structures, but following the situated processes as they evolve.

At The EdMedia World Conference on Educational Media and Technology in Denver, Colorado, June 2012, where we participated, there was a lively discussion among some presenters - among them the Canadian online learning researcher Linda Harasim (Harasim et al., 1995; Harasim, 2011) - on the perception of the term instructional design. Harasim viewed the term as a topdown approach, standardized, universalistic and fixed, with a strict division between a professional instructional designer planning the course and the actual teachers conducting the activities of a class (Harasim, 2011, p. 56). Other discussants, among them Tel Amiel and Thomas Reeves, pointed out that the instructional design paradigm is no longer the same as twenty years ago, and that today also instructional designers try to build a bridge to the practitioners in the classrooms and open up for customization and improved adaptability to the actual situation. The instructional design paradigm has therefore evolved into a broader understanding than originally.

Also Reigeluth (1999, p. 19) talks of a paradigm shift in the theory of instructional design towards a "learning-focused" paradigm as a result of the need for communication, problem solving and collaboration skills in the modern information society. Reigeluth states that while the industrial age encouraged standardization, bureaucratic organization, and centralized control, the next era encourages customization. Reigeluth argues that this change will force instructional design to switch from a passive learning system based with instructor control, to that of an active learning system, which will be learnercentered. Within the new paradigm learners must be able to take initiative so as to guarantee their own learning experience. They will need to know that they can be autonomous, but must understand that they are also accountable for their learning, and a large amount of the learning responsibility is thereby shifted to the learner (ibid.).

We acknowledge that the concept of instructional design has evolved. Focus of the approach is however still more on the instructor's perspective than on the student as participant. And in order to have focus on the learning that may unfold and the possible involvement of students as co-designers, we understand the paradigm on 'designs for learning' to be more in line with a perspective supporting a problem- and project-based learning approach.

Within the paradigm of 'designs for learning' focus is on the students' active learning processes and the creation of a learning environment that may foster dialogue, negotiation, sense making and genuine collaboration among the participants. 'Design' is both a noun and a verb, and therefore 'designs for 
learning' is referring as well to designing seen as a process and design seen as a product. Design is not only something you do before the practice. You design before, but you also design during practice. The tradition of 'designs for learning' thus builds on a constructivist view of learning, focusing on the mutual interaction between learners, teachers and peers in developing knowledge. The specific designs for learning should aim at supporting a flexible and situational communicative setup and thus provide support for communicative actions, which is, as we have seen, crucial for project groups.

In relation to the societal, organizational and educational changes, Karl Weick's metaphors for organizational planning and learning, discussed above, can be applied. Weick is skeptical about the common use of static architectural metaphors for organizational design and develops instead metaphors of improvisational theater as enabling coping with emergent and unforeseen events, as mentioned above (Weick, 2001,pp. 57ff). The design Weick aims to capture with the metaphor of improvisation is a pattern of interaction that is bottom-up and realized as a result of enacting 'the unknown'. This kind of 'improvisational design' seems to capture many of the processes meeting us in a situated learning context, where many decisions of professors as well as students have to be made in the midst of actions and cannot be planned and decided beforehand.

The continuous consideration and negotiation of strategies is also framed by Suchman, who in her book Plans and Situated Actions puts forward a critique of the then dominant cognitive science approach to technology design as it relied on an understanding of human activity where plans were directing actions. She advocated an alternative view, where plans are seen not as directions, but as potential resources for action, which need to be understood as they unfold in situ, and which should be continuously revised according to the new situations (Suchman, [1987] 2007; Simonsen et al., Chapter 1).

A parallel can be made to the participatory design tradition with its perspective of always looking forward to the shaping of future situations. Simonsen and Robertson define participatory design as "a process of investigating, understanding, reflecting upon, establishing, developing, and supporting mutual learning between multiple participants in collective 'reflection-inaction'." (Simonsen \& Robertson, 2013, p. 2). In this tradition there is an ongoing effort to deepen our understanding of how collaborative design processes can enable the participation of those, who will in the future be affected by their results: "The participants typically undertake the two principal roles of users and designers where the designers strive to learn the realities of the users' situation while the users strive to articulate their desired aims and learn appropriate technological means to obtain them" (ibid.). In problem- and project-organized studies students similarly experience the realities of different roles, being as well learners and designers of learning situations. Working consciously with the perspectives of different roles can be 
valuable for students as well as professors. In educational settings like MIL and Hum Tech it is crucial to be able to think along new lines in designing and re-designing learning experiences through continuous didactic experiments and activities. Such reflections regarding design can help professors and students to plan, implement, and evaluate educational activities.

\section{How to learn from projects?}

Relating the insights from the MIL case to the thoughts discussed above lead us to emphasize the following points, which are shown in Figure 1 and elaborated below, regarding how to learn from project work.

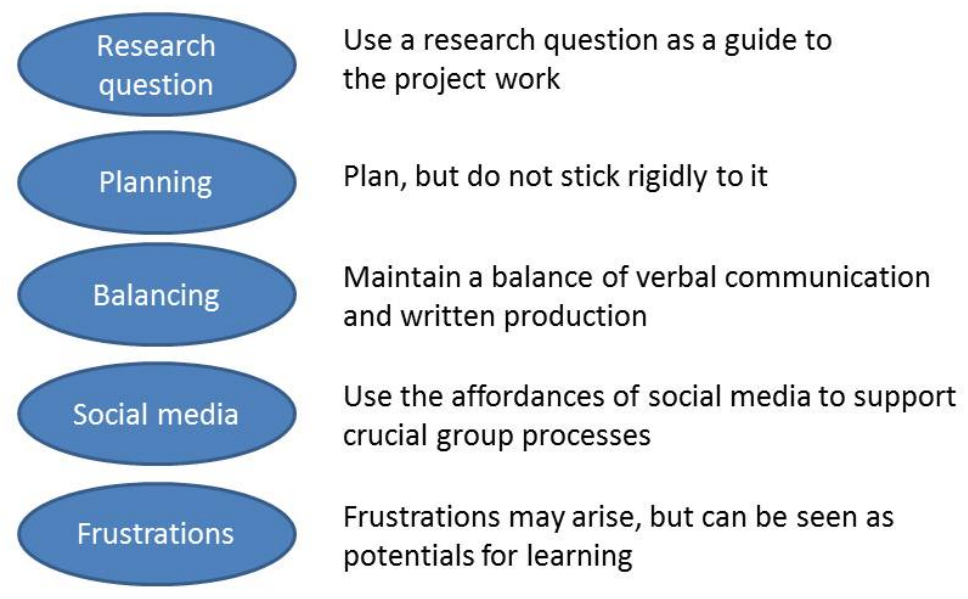

Figure 1. Learning from projects

- Use a research question as a guide to the project work

The aim of the students' own development of a research question for their project work is that such a question should act as a guide for the direction of the research process. When decisions are to be made during the process, the group can 'consult' their research question in order to decide what to do. In this process the research question is not to be phrased once and for all, but will need continuous evaluation and rephrasing.

- Plan, but do not stick rigidly to it

Adapt the plans continually to the specific situation, so that plans are not carried through without consideration, but are used as resources for situated action.

- Maintain a balance of verbal communication and written production 
It is often difficult in a student group to handle the balance between on the one hand developing insights through the groups' verbal discussions and on the other hand maintaining and developing these insights further by producing written text or constructing designs or artifacts.

- Use the affordances of social media to support crucial group processes

Social media, web 2.0, has made it easier to produce, publish, share and take part in collaborations. These affordances represent considerable changes and improvements in user's work practice and offer students a wide variety of flexible tools to be used in their project work.

- Frustrations may arise, but can be seen as potentials for learning

Be prepared that in the project work difficulties may develop that can lead to frustrations and sometimes conflicts between group members. However, such frustrations often occur because the existing view of things is not fully adequate, and new understandings are about to be developed. In this situation, differences between group members should not be seen exclusively as negative, but can be productive for the knowledge creation of the group. If used constructively, periods of frustration may thus be followed by breakthrough-experiences, 'we did it'!

Problem- and project-based learning can be seen as an active learning approach, characterized by multidisciplinarity. If successful, students may learn to collaborate, to plan their work processes, and to cope with unforeseen problems, hereby increasing the students' critical and creative thinking, selfesteem and motivation to work.

\section{Conclusion}

In this chapter it has been shown how design research can be related to the field of learning and how professors and students can design innovative and constructive study processes that can help meet the new needs for competencies arising from the change from an industrial society to a knowledge-based society. An insight was given to the American debate regarding design research and education, and different notions were lined up from the original type of research with more isolated and controlled environments, which characterized the tradition of instructional design, to researching learning processes in 'messy' real life situations, which characterized the tradition of design-based research in education. New paradigms have emerged, stressing the social dimensions of learning. Here a greater focus is on how learning and construction of knowledge is created through the interaction and active participation of students taking part in the learning processes.

An important focus of the chapter dealt with designing new and innovative learning processes within the tradition of problem- and project-based learning. 
Important here is to see students not only as co-designers, but as independently and collaboratively designing and having ownership over their own projects. In the present context with rapidly evolving new social media and active user involvement, problem- and project-based learning approaches gain new relevance in the interplay with new technological possibilities. Of importance is to have in view the specificity of situatedness. In complex changing study settings, students must be able to engage in negotiations and nothing can be taken for granted, as pointed out by Weick and Suchman.

Through the MIL case it was demonstrated how we as a team of professors have been continually working on designing and re-designing the educational program in interaction with the students. Processes involved in developing 'master projects' were demonstrated and discussed through articulations and reflections made by MIL students regarding collaboration with peer-students and regarding their relations and attitudes to teachers as supervisors.

\section{References}

Alvesson, Mats. "Methodology for close up studies - struggling with closeness and closure." Higher Education 46, no. 2 (2003): 167-193.

Andreasen, Lars B., and Jørgen L. Nielsen. "Dimensions of problem based learning - dialogue and online collaboration in projects." Journal of Problem Based Learning in Higher Education 1, no. 1 (2013): 210-229.

Barab, Sasha A., and Kurt Squire. "Design-Based Research: Putting a Stake in the Ground." Journal of the Learning Sciences 13, no. 1 (2004): 1-14.

Barrett, Terry, and Sarah Moore. New approaches to problem-based learning: Revitalizing your practice in higher education. New York: Routledge, 2011.

Barron, Brigid J. S., Daniel L. Schwartz, Nancy J. Vye, Allison Moore, Anthony Petrosino, Linda Zech, John D. Bransford, The Cognition and Technology Group at Vanderbilt. "Doing with Understanding: Lessons from Research on Problem- and Project-Based Learning." Journal of the Learning Sciences 7, no. 3/4 (1998): 271-311.

Brown, Ann L. "Design experiments: Theoretical and methodological challenges in creating complex interventions in classroom settings." Journal of The Learning Sciences 2, no. 2 (1992): 141-178.

Collins, Allan. "Toward a design science of education." In New directions in educational technology, edited by E. Scanlon, and T. O'Shea, 15-22. New York: Springer-Verlag, 1992.

Collins, Allan, Diana Joseph, and Kate Bielaczyc. "Design Research: Theoretical and Methodological Issues." Journal of the Learning Sciences 13, no. 1 (2004): 15-42. 
Christensen, Ove, Karsten Gynther, and Trine B. Petersen. "Design-Based Research - introduktion til en forskningsmetode i udvikling af nye Elæringskoncepter og didaktisk design medieret af digitale teknologier" ('Design Based Research - introduction to a research methodology to develop new e-learning concepts and didactic design mediated by digital technologies"). Laring \& Medier (LOM) 5, no. 9 (2012): 1-20.

Dirckinck-Holmfeld, Lone. "Designing virtual learning environments based on problem oriented project pedagogy." In Learning in virtual environments, edited by Lone Dirckinck-Holmfeld, and Bo Fibiger, 31-54. Frederiksberg: Samfundslitteratur, 2002.

Dirckinck-Holmfeld, Lone, Torben Iversen, Ulla Konnerup, Merete Lindemann, Steener Oksbjerre, Torben Pihler, Marianne Riis, and Dorte S. Schmidt. "Når specialer gør en forskel - om kollaborative arbejdsformer i virtuelle læremiljøer" ("When master projects make a difference studying collaboratively in virtual learning environments"). In Digitale medier og didaktisk design ("Digital media and didactic design"), edited by Lars B. Andreasen, Bente Meyer, and Pernille Rattleff, 169-191. Copenhagen: Danish University of Education Press, 2008.

Ejersbo, Lisser R., Robin Engelhardt, Lisbeth Frølunde, Thorkild Hanghøj, Rikke Magnussen, and Morten Misfeldt. "Balancing Product Design and Theoretical Insight." In The Handbook of Design Research Methods in Education, edited by A. E. Kelly, R. A. Lesh, and J. Y. Baek, 149-163. Mahwah, NJ: Lawrence Erlbaum, 2008.

Frank, Moti, and Abigail Barzilai. "Project-based technology: Instructional strategy for developing technological literacy." Journal of Technology Education 18, no. 1 (2006): 39-53.

Harasim, Linda, Starr R. Hiltz, Lucio Teles, and Murray Turoff. Learning Networks: A Field Guide to Teaching and Learning Online. Cambridge: MIT Press, 1995.

Harasim, Linda. Learning Theory and Online Technology: How New Technologies are Transforming Learning Opportunities. New York: Routledge Press, 2011.

Hertzum, Morten (Chapter 4 in this volume). Project Designs for Student Design Projects.

Kahiigi, Evelyn K., Love Ekenberg, Henrik Hansson, F. F. Tusubira, and Mats Danielson. "Exploring the e-Learning State of Art." Electronic Journal of e-Learning 6, no. 2 (2008): 77-88.

Kemmis, Stephen, and Mervyn Wilkinson. "Participatory action research and the study of practice." In Action research in practice: Partnerships for social justice in education, edited by Bill Atweh, Stephen Kemmis, and Patricia Weeks, 21-36. London: Routledge, 1998. 
Kensing, Finn, and Joan M. Greenbaum. "Heritage: having a say." In Routledge international Handbook of Participatory design, edited by Jesper Simonsen, and Toni Robertson, 21-36. New York: Routledge, 2013.

Kolmos, Anette, Flemming Fink, and Lone Krogh, eds. The Aalborg PBL model - Progress, diversity and challenges. Aalborg: Aalborg University Press, 2004.

Nielsen, Jørgen L., and Lars B. Andreasen. "Educational Designs Supporting Student Engagement through Networked Project Studies." In Increasing Student Engagement and Retention using Mobile Applications: Smartphones, Skype and Texting Technologies. (Cutting-Edge Technologies in Higher Education, vol. 6D), edited by Laura Wankel, and Patrick Blessinger, 19-46. Bingley, UK: Emerald Publishing Group, 2013.

Nielsen, Jørgen L., and Oluf Danielsen. "Problem-oriented project studies: The role of the teacher as supervisor for the study group in its learning processes." In Exploring the theory, pedagogy and practice of networked learning, edited by Lone Dirckinck-Holmfeld, Vivien Hodgson, and David McConnell, 257-272. New York: Springer, 2012.

Olesen, Henning S., and Jens H. Jensen, eds. Project studies - A late modern university reform? Frederiksberg: Roskilde University Press, 1999.

Olsen, Poul B., and Kaare Pedersen.Problem-oriented project work - A workbook. Frederiksberg: Roskilde University Press, 2005.

O'Reilly, Tim. "What Is Web 2.0: Design Patterns and Business Models for the Next Generation of Software." Communications \& Strategies, no. 65 (2007): 17-37.

Reigeluth, Charles. "What is Instructional-Design Theory and How Is It Changing?" In Instructional-design theories and models: A new paradigm of instructional theory, volume ii, edited by Charles Reigeluth, 5-30. New Jersey: Lawrence Erlbaum Associates, 1999.

Revans, Reginald. The Origins and Growth of Action Learning. Brickley, UK: Chartwell-Bratt, 1982.

Schön, Donald A. The Reflective Practitioner. New York: Basic Books, 1983.

Schön, Donald A. Educating the Reflective Practitioner - Toward a New Design for Teaching and Learning in the Professions. San Francisco: Jossey-Bass Publishers, 1987.

Selander, Staffan. "Designs for learning - A Theoretical Perspective". Designs for Learning 1, no. 1 (2008): 10-22.

Simonsen, Jesper, Connie Svabo, Morten Hertzum, Sara Malou Strandvad, Kristine Samson, and Ole Erik Hansen. (Chapter 1 in this volume). Introduction. 
Simonsen, Jesper, and Toni Robertson. "Participatory Design: an introduction." In Routledge international Handbook of Participatory design, edited by Jesper Simonsen, and Toni Robertson, 1-17. London: Routledge, 2013.

Suchman, Lucy. Plans and situated actions - The problem of human-machine communication. $2^{\text {nd }}$ edition. New York: Cambridge University Press, [1987] 2007.

Weick, Karl E. "Educational organizations as loosely coupled systems." Administrative Science Quarterly 21, no. 1 (1976): 1-19.

Weick, Karl E. Making sense of the organization. Malden, Ma: Blackwell Business, 2001.

Wenger, Etienne. Communities of Practice. Learning, Meaning, and Identity. Cambridge: Cambridge University Press, 1998. 